\title{
APPLICATION OF RADIATION PROCESSES FOR TESTING OF GAS TURBINE BLADES
}

\author{
M.I. Bazaleev ${ }^{1}$, V.V. Bryukhovetsky ${ }^{1}$, S.Ye. Donets ${ }^{1}$, V.F. Klepikov ${ }^{1}$, V.V. Lytvynenko ${ }^{1}$, \\ E.M. Prokhorenko , O.A. Startsev ${ }^{1}$, Yu.F. Lonin ${ }^{2}$, A.G. Ponomarev ${ }^{2}$, V.T. Uvarov ${ }^{2}$ \\ ${ }^{1}$ Institute of Electrophysics and Radiation Technologies, Kharkiv, Ukraine; \\ ${ }^{2}$ National Science Center "Kharkov Institute of Physics and Technology", Kharkiv, Ukraine \\ E-mail: vvlytvynenko@ukr.net
}

Structural integrity of the gas turbine blades is of great concern. A set of methods and instruments is proposed to study the problems of the test loading of the industrial turbine blades. The approach aims to model the possible hightemperature, shock and irradiation impacts. The test loading is performed using the high-current relativistic electron beam. The developed methodology can be used for test and identification trails of the turbine blades. The experimental bench is designed to assist the thermographic measurements of the temperature dynamics in the blades. It also comprises the corresponding algorithms and software to perform the necessary calculations with.

PACS: 07.05.Tp, 61.80.Fe, 81.70.-q, 87.63.Hg

\section{INTRODUCTION}

At present moment, the prolongation of lifespan and enhancement of reliability of gas turbine engines is of great importance. Turbine blades are a part of an engine which is most sensitive to the damage. Blades may be damaged by high temperatures and stresses, corrosion, creep and fatigue $[1,2]$. These problems provided a major impetus for the development of the progressive technologies to manufacture the turbine blades, such as molding with directional crystallization, the application of protective coatings, the development of special alloys and protective composites [3 - 5]. However, there are some major problems which are of large concern. The problem of surface roughness still remains, which significantly affects the formation of impact loads, especially when switching the engine from one mode of load to another.

The next issue is identification and elimination of the surface roughness of the cooling channels. Since one of the predominant mechanisms of blade fracture is lowcycle and thermal fatigue [6], then empirically the surface quality of the cooling channel and the exterior surface of the blade will determine the spatial distribution of the temperature fields and the fields of mechanical stresses. Their distributions determine the intensity of wear and destructive influence. Hereupon, it is essential to develop comprehensive tools to reduce the surface porosity and to minimize the possible heterogeneities and technological burrs in the cooling channels of the blades. The active thermographic control methods are applied to facilitate the detection of the possible faults in the turbine blades.

In literature, some research results were reported about the numerical simulation of the distribution of temperature and mechanical fields at normal workloads, taking into account the thermal expansion of the channels and centrifugal forces of loading [7]. However, the importance of development of experimental techniques remains relevant to enhance the understanding of the damage mechanisms of blades and to apply the experimental methods to validate the calculated data.

Another issue is how to model experimentally the critical loads applied to the turbine blades. Such loads should include large bulk temperature gradients and formation of heterogeneously distributed stress fields. A promising step in refinement of the production of the industrial gas turbine blades is the integration of radiation technologies into existing technological processes, which allows for the transfer of production to a higher technological order and the opening of new technological directions of development in the shortest possible time. Concentrated energy flows have successful applications in power engineering (incl. engineering of gas turbine engines). For example, powerful laser radiation is used both for melt/vapor deposition of protective coatings on the turbine blades, and to remove some layers that are formed during operation [8]. Ion beams are used to strengthen the surface by ion implantation into the surface layer. High-current low-energy electron beams are utilized to restore worn-out surfaces by deposition of some reinforcing materials onto them. Subsequent reirradiation can be applied to achieve a higher adhesion to the main substrate and/or to form new compounds with higher performance characteristics, incl. higher resistance to extreme loads [9]. The energies of electrons in the latter case are $115 \ldots 125 \mathrm{keV}$. However, there is a certain technological niche for the use of the electron accelerators with energies of $150 \ldots 350 \mathrm{keV}$. The accelerators of high-current electron beams of the specified range of energies were created for the implementation of certain projects for thermonuclear fusion, the generation of microwave electromagnetic radiation, etc. The Ni-based superalloys are designed and continuously improved to withstand the harsh operation conditions $[10,11]$. Regarding the mentioned set of issues and goals, it is necessary to enlarge the variety of advanced methods and instruments to assist the research using the extreme test loading of the turbine blades, where HCEB can be applied as well. Extreme loading aims to model the high temperature, shock and irradiation impacts on the metal. HCEB is a flexible instrument for modification and testing of wide range of materials [12 - 14].

If the HCEB testing conditions are compared with the industrial operational conditions of the turbine blades, the testing conditions can be flexibly changed and they may greatly surpass the critical operational values in order to model the catastrophic events. For example, recently, modelling of the temperature distri- 
butions in the gas turbine rotor blades with internal cooling passages was conducted in [15]. It was shown, that the maximum temperatures just a little below the melting temperature are reached on the leading edge of the blade, while the minimum temperature is on the tailing edge with a difference of about $200 \mathrm{~K}$ with respect to the maximum temperature. The maximum heat flux on the leading edge is around $0.25 \mathrm{MW} / \mathrm{m}^{2}$. From the perspective of the HCEB testing, these conditions can be exceeded greatly but for a short period of time. The average heat flux on the surface during HCEBirradiation is around $50 \mathrm{GW} / \mathrm{m}^{2}$, while the maximum heat flux is even higher by an order of magnitude. The limited duration of irradiation may be used as an advantage to simulate the initial stage of the possible emergency/catastrophic event. The supplied energy dose by HCEB reaches up to $10 \mathrm{MJ} / \mathrm{m}^{2}$.

This article presents the results about the local customization of the active thermographic analysis for the faults detection in the turbine blade, and about the test loading of the turbine blade under the impact of intense microsecond quasirelativistic electron beam.

\section{MATERIALS AND METHODS}

The industrial turbine blade protected by the proprietary rights was provided for this research. A piece was cut from the turbine blade using a disc saw. That sample was irradiated at the TEMP-A e-beam accelerator facility in the "NSC Kharkov Institute of Physics and Technology". The thickness of the piece greatly surpassed the maximum affected depth by the electron exposure. The parameters of the beam were the following: the current of $2 \mathrm{kA}$, electron energy $\sim 350 \mathrm{keV}$, the impulse duration $\tau_{p} \sim 5 \mu \mathrm{s}$. The beam had the solid shape of cross-section with the radius about $20 \mathrm{~mm}$, and the Gaussian distribution of intensity in its cross-section. The incident beam targeted the sample perpendicularly. The trace of the beam was not completely within the sample's surface, and $1 / 3$ of the beam did not interact with the sample. The irradiation was performed under the pressure of $10^{-5}$ Torr.

Numerical modelling of the distributions of temperature and displacement fields during the corresponding HCEB irradiation was conducted using the finite element and finite difference approaches. The 2D thermoelastic ablation model was used for calculations. The details of this model are described elsewhere [13]. The numerical modelling was performed using the free-source partial differential equation solver FreeFem++v3.61 [16].

The chemical composition of the alloy used in this research is $\mathrm{Ni}-14 \mathrm{Cr}-9 \mathrm{Co}-2 \mathrm{Mo}-4 \mathrm{~W}-3 \mathrm{Al}-4 \mathrm{Ti}-5 \mathrm{Ta}-0.3 \mathrm{Ha}-$ $0.1 \mathrm{Nb}$. It is not the exact composition due to the proprietary rights and some other elements as $\mathrm{Re}$ and $\mathrm{Ru}$ may present. The parameters of the alloy utilized in the calculations are: the mean atomic mass $A=69.2$, the mean atomic charge $Z=31.2$, the density is $\rho=$ $8.1 \mathrm{~kg} \cdot \mathrm{m}^{-3}$, the specific heat $\mathrm{c}=630 \mathrm{~J} \cdot \mathrm{kg}^{-1} \cdot \mathrm{K}^{-1}$, the thermal conductivity $\mathrm{k}=100 \mathrm{~W} \cdot \mathrm{m}^{-1} \cdot \mathrm{K}^{-1}$, the approximate melting temperature $\mathrm{T}_{\text {melt }}=1600 \mathrm{~K}$, the initial reference temperature of the sample $\mathrm{T}_{0}=290 \mathrm{~K}$, the Young's modulus $\mathrm{E}=140 \mathrm{GPa}$, the Poisson's ratio $\mathrm{v}=0.3$, the thermal expansion $\alpha_{\mathrm{T}}=14 \cdot 10^{-6} \mathrm{~K}^{-1}$, the ratio of the specific heats of solid medium to generated plasma $\eta_{\text {eff }}=$
1.2, the absorption coefficient $\varepsilon=0.9$, the duration of impulse $\tau_{\mathrm{p}}=5 \cdot 10^{-6} \mathrm{~s}$, the relaxation time $\tau_{\mathrm{r}}=10^{-11} \mathrm{~s}$, the refractive index of environment $\mathrm{m}=1$, the integral emissivity $\varepsilon_{\mathrm{R}}=0.5, \sigma_{\mathrm{R}}=5.67 \cdot 10^{-8} \mathrm{~W} \cdot \mathrm{m}^{-2} \cdot \mathrm{K}^{-4}$, and the total beam current $\mathrm{J}=2 \cdot 10^{3} \mathrm{~A}$, the acceleration voltage $\mathrm{U}=0.35 \cdot 10^{6} \mathrm{~V}$. Worth nothing, the mentioned thermophysical coefficients were taken as provided without consideration of their temperature dependencies. The medium was continuous. The crystallographic orientations were not taking into account.

The infrared camera Fluke 32Ti was used to monitor the dynamics of temperature fields in the turbine blades. The instrument error is estimated to be about $0.05 \mathrm{~K}$. The standard software by Fluke was used to treat the acquired thermographs. The numerical modelling of the temperature dynamics was conducted using the proprietary software developed by the authors of this article.

\section{RESULTS AND DISCUSSION 2.1. THERMOGRAPHIC ANALYSIS}

Application of IR remote monitoring of the temperature field of the gas turbine blade as a tool to assess the thermal stress state and detection near-critical faults is well known [6]. For instance, in [6] there was installed a pyrometer module, which measured the temperature during the operation of the engine, simultaneously analyzing the received signal. At the same time, there is a problem of identification of the blades, which may experience the excessive temperature gradients along their chords with a change in applied loads. This is usually due to the deviations in the surface geometry of the cooling channels of the blades (e.g., caused by the high surface roughness). At the same time, an increase of the surface roughness by means of the rib turbulators intensifies the heat transfer and increases the efficiency and durability of the gas turbine engines [17]. Identification of the defects in the turbine blades using introscopy may not be possible (e.g., X-ray imaging). Since the damage is predominantly done by the excessive thermal stresses, the reliable detection of the damaged specimens lies in the careful measurement of temperature distribution on the surface and analysis of its dynamics. The methods of active thermographic monitoring can be applied for this purpose [18]. While heating the blade by passing the electric current or by induction heating [18], the damaged area is identified due to its differences in the electro-physical characteristics with respect to the reference area. Another mechanism of activation of the temperature field is the vibrational effect, which reproduces the operational load of vibrations causing the excessive concentration of thermal energy in some origin and further development of a crack.

A special test bench for a comprehensive control (Fig. 1) was developed for this project. The test bench consists of the multiple heating sources: ultrasonic sources and hot air flows. Such an approach was taken to combine the vibrational effects and thermal loads, so it better reproduces the real operational conditions. Separately, the issue with the thermal anomalies arises due to presence of the heterogeneities on the surface of the cooling channel. To cope with this issue, the testing of the cooling channel is performed applying a constant 
source of heat, which is a flexible thermoelectric element placed in the channel. This complexity of the proposed approach distinguishes it from the test bench described in [19].

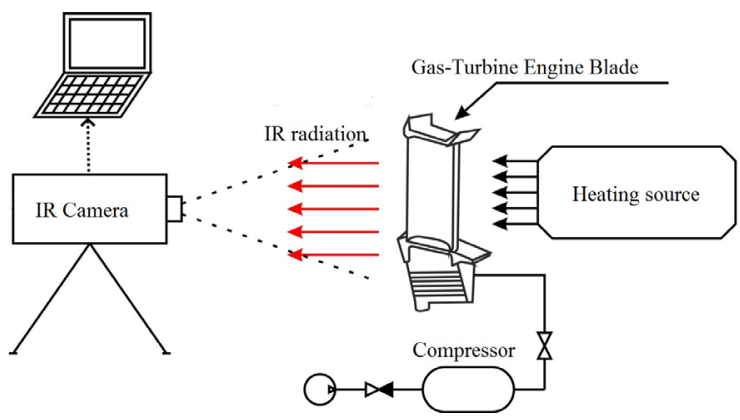

Fig. 1. Schema of thermographic inspection of temperature distribution in the gas turbine blade

Implementing the active thermographic monitoring related to the detection of the initial stage of the origin of fatigue cracks, our model considers the process of transformation of the energy of cyclic stresses into thermal energy due to elastic and plastic displacements of crystalline lattices [20]:

$$
\rho C T-\kappa \nabla^{2} T=-\frac{E \alpha T_{0}}{(1-2 v)} \sum_{i=1}^{3} \dot{\varepsilon}_{n n}+\sigma \dot{\varepsilon}_{n p},
$$

where $\rho$ is the density, $C$ is the specific heat, $T$ denotes the temperature, $E$ is the Young's modulus, $\alpha$ is the coefficient of thermal expansion, $T_{0}$ is the initial reference temperature, $v$ is the Poisson's ratio, $\varepsilon_{n n}$ is the elastic strain tensor, $\varepsilon_{n p}$ is the plastic strain tensor, and $\sigma$ is the stress tensor.

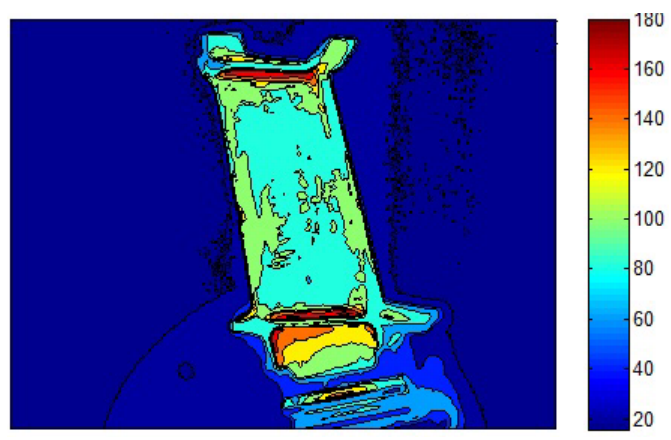

Fig. 2. Thermographic image of the gas turbine blade obtained using the segmentation method

In order to illustrate the temperature distributions, it is necessary to employ the similarity criteria, which are influenced by the surface roughness of the cooling channels in the blade. The segmentation method was used to visualize the data (Fig. 2). The potentially critical zones were identified using the method of analysis of the gradient images applying segmentation by the watershed transformation. The gradient values of the reference image were calculated by approximation of the gradient operator in the $x$ and $y$ directions. At the next step, the gradient filter separates the highfrequency component of images, which represents the highest changes of temperature (Fig. 3).

The searching procedure of the critical zones targets certain areas, where the first derivative of the image's intensity is higher than a certain threshold, which is cal- culated using a standard not-defective blade, and the areas at the inflection points.

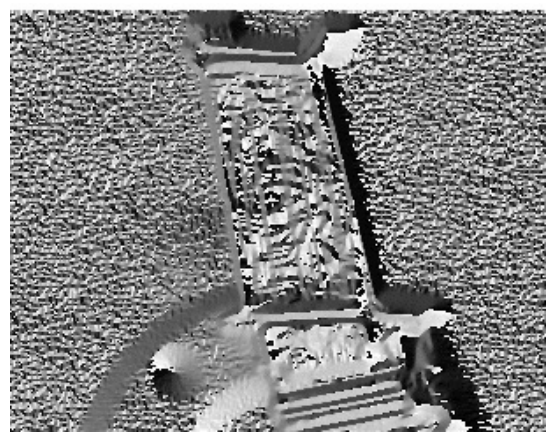

Fig. 3. The image of gradient module of the corresponding segmented thermographic image (see Fig. 2)

\subsection{HCEB TEST LOADING}

Fig. 4 shows the sample of the gas turbine blade after the end of one HCEB irradiation impulse. On this figure, the sample is fixed to the accelerator's removable sample holder. The HCEB irradiation resulted in the melting of the surface. No cracks were found in the blade.

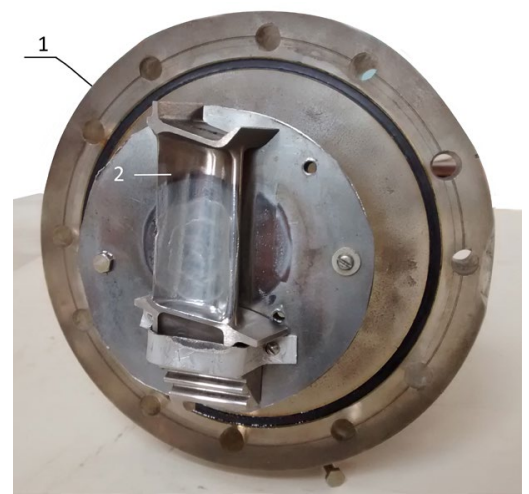

Fig. 4. The specimen (2) mounted on the collector (1) after irradiation with $H C E B$

The numerical simulation of the HCEB irradiation was also performed (Fig. 5). The simulations have shown, that the applied conditions led to the intense surface melting reaching about $2900^{\circ} \mathrm{C}$. The displacement distribution is presented on Fig. 5,a and the distribution of the temperature field is shown on Fig. 5,b. These fields were obtained for the $2 \mathrm{D}$ cross-section towards depth.

The HCEB irradiation resulted in a rapid heating of the thin surface layer with a depth up to $0.4 \mathrm{~mm}$ in the epicenter of irradiation. The epicenter acquired a dose around $10 \mathrm{MW} / \mathrm{m}^{2}$. In contrary to the light alloys studied previously in $[12,13]$, where the irradiation induced ablation of the medium from the volume, in the case of this heat-resistant material, the ablation mode has a profound surface character. The calculated energy deposition of quasirelativistic electrons of $350 \mathrm{keV}$ has a peak at a depth around $48 \mu \mathrm{m}$ and a maximum propagation depth around $150 \mu \mathrm{m}$. Thus, the ablation of the material [21 - 23] goes in the thermal mode. In the recent research, similar phenomenon of the increase of surface ablation rather than from the volume was observed for the steels [14] and for $\mathrm{Zr} 1 \% \mathrm{Nb}$ [24 - 26]. 

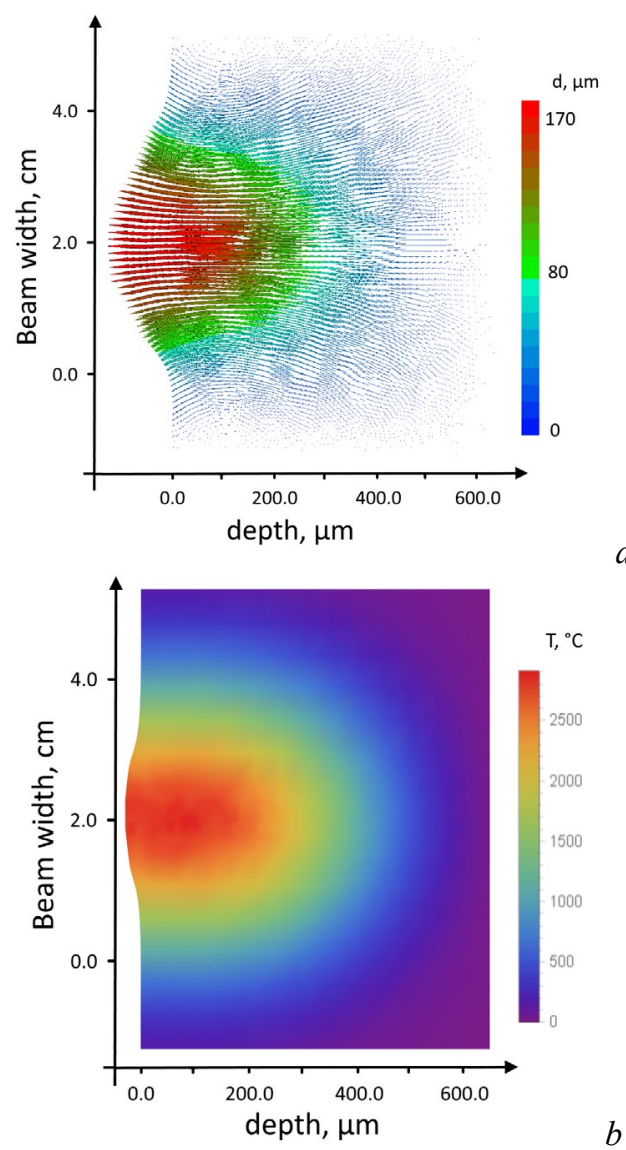

Fig. 5. Numerical modelling of the heat-resistant Ni-based alloy after HCEB irradiation: (a) vector plot of the $2 D$ displacement field, and (b) temperature distribution

The calculated displacements reached up to $180 \mu \mathrm{m}$ during fast heating in the epicenter of the crater (see Fig. 3). The residual compressive stresses at the surface after irradiation and subsequent thermal relaxation are estimated to be around $(400 \pm 50) \mathrm{MPa}$, and no delamination of the modified layer is expected.

The presented research will be further extended to simulation of the emergency/catastrophic events of the turbine blades under the HCEB testing impact with the initial real operation conditions (elevated initial temperature, high pressure).

\section{CONCLUSIONS}

The research presents the application of the thermographic methods and HCEB irradiation to study the problems of quality assurance and test loading of the industrial gas turbine blades. The active thermographic control was adopted to distinguish the faults in the turbine blade. The test bench was designed and the software package for data treatment was developed for the thermographic analysis of the blade. HCEB exposure was used to imitate the overheating and critic/ catastrophic events of the blade. The numeric simulations of the temperature, displacement, and mechanical stress distributions in the target were performed using the thermoelastic ablation model. It was found, that the applied HCEB exposure was conducted in the thermal mode of ablation, which characterizes with the predominant surface component in contrary to the volume effects.

\section{ACKNOWLEDGMENT}

The research presented in this article was conducted by financial support of the state budget program "Support for the development the priority areas of scientific researches" (Budget Financial Code 6541230).

\section{REFERENCES}

1. T.J. Carter. Common failures in gas turbine blades // Engineering Failure Analysis. 2005, v. 12(2), p. 237-247.

2. J.-C. Han. Fundamental Gas Turbine Heat Transfer // Journal of Thermal Science and Engineering Applications. 2013, v. 5, p. 021007.

3. A.V. Boguslayev, V.V. Murashko. Gazotsirkulyacionnoye pokrytie lopatok turbiny gazoturbinnyh dvigateley // Vestnik dvigatelestroeniya. 2006, № 4(6), p. 73-75 (in Russian).

4. C.A. Estrada M. New technology used in gas turbine blade materials // Scientia et Technica Año XIII, 2007, № 36, Universidad Tecnológica de Pereira, p. 297-301.

5. I.G. Kvasnytska. Improving the performance of working blades of modern industrial gas turbine engines // Metall i Litye Ukrainy. 2015, № 8 (267), p. 29-31 (in Russian).

6. E.V. Rastoropov et al. Informatsionnaya tehnologiya integracii intelectuaklnogo pirometricheskogo modulya $\mathrm{V}$ systemu upravlenita, kontrolya $\mathrm{S}$ diagnostiki (FADEC) GTD // Vestnik UGATU. T 14, № (38), p. 101-110 (in Russian).

7. Iu.S. Vorobiov et al. Vibration characteristics of cooled single-crystal gas turbine blades // Journal of Vibrational Engineering and Technologies. 2014, v. 2, № 6, p. 537-541.

8. S.I. Plankovskiy et al. Considering of the existent techniques of cleaning turbine blade surface in gas turbine engines // Aerospace Technic and Technology. 2013, № 6 (103), p. 8-14.

9. V.A. Shulov et al. Application of High-Current Pulsed Electron Beams for Modifying the Surface of Gas-Turbine Engine Blades // Russian Journal of Non-Ferrous Metals. 2016, v. 57, № 3, p. 256-265.

10. J.Q. Peng, H.T. Zhang, Y.F. Li. Review of Blade Materials for IGT // Procedia Engineering. 2015, v. 130 , p. 668-675.

11. I.G. Kvansnytska. Improving the performance of working blades of modern industrial gas turbine engines // Metal and Cast. 2015, v. 267, № 8, p. 2931 .

12. A.G. Kobets et al. Melting effects of high-current relativistic electron beam on aluminum alloy 1933 // Surface Engineering and Applied Electrochemistry. 2015, v. 51, № 5, p. 478-482.

13. V.F. Klepikov et al. Physical and mechanical properties of titanium alloy VT1-0 after high-current electron beam irradiation // Problems of Atomic Science and Technology. 2015, № 2, p. 39-42.

14. S.V. Bytkin et al. The features of the modified treatment of the low-carbon steels by the highcurrent relativistic electron beams // Journal of Nano- and Electronic Physics. 2017, v. 9(4), p. 04013-1-04013-6. 
15. G. Cheemanapalle, S.P. Kumar, S. Bezawada. Modelling of gas turbine rotor blade with internal cooling passages // International Journal for Research in Applied Science \& Engineering Technology. 2016, v. 4(III), p. 419-426.

16. F. Hecht. New development in FreeFem++ // Journal of Numerical Mathematics. 2012, v. 20, № 3-4, p. 251-266.

17. A.A. Khalatov et al. High performance gas turbine blade cooling: trends of development. Part 2. Perspective cooling schemes // Prom. teplotehnika. 2010, v. 32, № 2, p. 60-72 (in Russian).

18. J. Vrana, M. Goldammer. Induction and Conduction Thermography: From the Basics to Application // Thermographie-Kolloquium. 2017.

19. B.N. Bazhenov et al. Metod teplovoy defectoskopii lopatok turbin // Aerospace Technic and Technology. 2007, № 7(43), p. 63-66.

20. T. Ummenhofer, J. Medgenberg. Numerical modeling of thermoelasticity and plasticity in fatigue-loaded low carbon steels // QIRT Journal. 2006, v. 3, № 1, p. 71-91.

21. V.V. Uvarov et al. The dynamics of the gas - plasma torch induced by the high current REB on solid state targets // Problems of Atomic Science and Technology. Series “Plasma Physics”. 2009, № 1, p. $119-121$
22. V.B. Tarelnyk et al. Investigation of Regularities of the Processes of Formation of Surface Layers with Electroerosive Alloying. Part II // Metallofiz. Noveishie Tekhnol. 2017, 39, № 3, p. 363-385 (in Russian).

23. S.Ye. Donets et al. Aluminum surface coating of copper using high-current electron beam // Problems of Atomic Science and Technology. Series "Plasma Electronics and New Methods of Acceleration". 2015, № 4, p. 302-305.

24. O.A. Startsev et al. Behavior of $\mathrm{Zr} 1 \% \mathrm{Nb}$ Alloy under Swift $\mathrm{Kr}$ Ion and Intense Electron Irradiation // Journal of Nano- and Electronic Physics. 2015, v. 7, № 4, p. 04016.

25. A.B. Batracov et al. The particularities of the high current relativistic electron beams influence on construction materials targets // Problems of Atomic Science and Technology. Series "Nuclear Physics Investigations". 2013, v. 6, p. 225-229.

26. V.F. Klepikov et al. The formation of strengthening coats by microsecond duration high-current relativistic electron beam // Problems of Atomic Science and Technology. Series "Nuclear Physics Investigations”. 2008, № 5, p. 91-95.

Article received 05.06.2019

\section{ПРИМЕНЕНИЕ РАДИАЦИОННЫХ ПРОЦЕССОВ ДЛЯ ИСПЫТАНИЙ ЛОПАТОК ГАЗОТУРБИННЫХ ДВИГАТЕЛЕЙ}

\section{М.И. Базалеев, В.В. Брюховецкий, С.Е. Донец, В.Ф. Клепиков, В.В. Литвиненко, Е.М. Прохоренко, А.А. Старцев, Ю.Ф. Лонин, А.Г. Пономарёв, В.Т. Уваров}

Предложены методы и инструменты для решения задач экстремальной тестовой нагрузки на лопатки турбин, которые бы воспроизводили возможные высокотемпературные, ударные и радиационные воздействия. Разработан подход, основанный на использовании сильноточного релятивистского электронного пучка. На основании этого создана методика проведения тестовых и идентификационных испытаний лопаток газотурбинных двигателей. Разработаны экспериментальный стенд для термографического измерения динамики распределения температурного поля на поверхности лопатки и соответствующие алгоритмы и программное обеспечение для проведения необходимых расчетов.

\section{ЗАСТОСУВАННЯ РАДІАЦЙНИХ ПРОЦЕСІВ ДЛЯ ВИПРОБУВАНЬ ЛОПАТОК ГАЗОТУРБІННИХ ДВИГУНІВ}

\section{М.І. Базалєєв, В.В. Брюховецький, С.С. Донець, В.Ф. Клепіков, В.В. Литвиненко, С.М. Прохоренко, О.А. Старцев, Ю.Ф. Лонін, А.Г. Пономарьов, В.Т. Уваров}

Запропоновано методи та інструменти для вирішення задач екстремального тестового навантаження на лопатки турбін, які б відтворювали можливі високотемпературні, ударні та опромінювальні впливи. Розроблено підхід, що грунтується на використанні сильнострумового релятивістського електронного пучка. На підставі цього створено методику проведення тестових та ідентифікаційних випробувань лопаток газотурбінних двигунів. Розроблені експериментальний стенд для термографічного вимірювання динаміки розподілу температурного поля на поверхні лопатки та відповідні алгоритми і програмне забезпечення для проведення необхідних розрахунків. 